\title{
Organic composition of carbonaceous aerosols in an aged prescribed fire plume
}

\author{
B. Yan ${ }^{1}$, M. Zheng ${ }^{1}$, Y. T. Hu ${ }^{2}$, S. Lee ${ }^{1, *}$, H. K. Kim ${ }^{2}$, and A. G. Russell ${ }^{2}$ \\ ${ }^{1}$ School of Earth and Atmospheric Sciences, Georgia Institute of Technology, Atlanta, GA, USA \\ ${ }^{2}$ School of Civil and Environmental Engineering, Georgia Institute of Technology, Atlanta, GA, USA \\ *currently at: Measurement Support Center, Division of Quality of Life, Korea Research Institute of Standards and Science, \\ Daejeon, Republic of Korea
}

Received: 13 November 2007 - Published in Atmos. Chem. Phys. Discuss.: 17 December 2007

Revised: 9 September 2008 - Accepted: 9 September 2008 - Published: 10 November 2008

\begin{abstract}
Aged smoke from a prescribed fire (dominated by conifers) impacted Atlanta, GA on 28 February 2007 and dramatically increased hourly ambient concentrations of $\mathrm{PM}_{2.5}$ and organic carbon (OC) up to 140 and $72 \mu \mathrm{g} \mathrm{m}^{-3}$, respectively. It was estimated that over 1 million residents were exposed to the smoky air lasting from the late afternoon to midnight. To better understand the processes impacting the aging of fire plumes, a detailed chemical speciation of carbonaceous aerosols was conducted by gas chromatography/mass spectrometry (GC/MS) analysis. Ambient concentrations of many organic species (levoglucosan, resin acids, retene, $n$-alkanes and $n$-alkanoic acids) associated with wood burning emission were significantly elevated on the event day. Levoglucosan increased by a factor of 10 , while hopanes, steranes, cholesterol and major polycyclic aromatic hydrocarbons (PAHs) did not show obvious increases. Strong odd over even carbon number predominance was found for $n$-alkanes versus even over odd predominance for $n$-alkanoic acids. Alteration of resin acids during transport from burning sites to monitors is suggested by the observations. Our study also suggests that large quantities of biogenic volatile organic compounds (VOCs) and semivolatile organic compounds (SVOCs) were released both as products of combustion and unburned vegetation heated by the fire. Higher leaf temperature can stimulate biogenic VOC and SVOC emissions, which enhanced formation of secondary organic aerosols (SOA) in the atmosphere. This is supported by elevated ambient concentrations of secondary organic tracers (dicarboxylic acids, 2-methyltetrols, pinonic acid and pinic acid). An approximate source profile was built
\end{abstract}

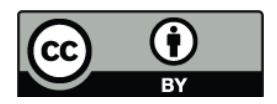

Correspondence to: A. G. Russell (ted.russell@ce.gatech.edu) for the aged fire plume to help better understand evolution of wood smoke emission and for use in source impact assessment.

\section{Introduction}

Wildland fire (wild fire and prescribed burning) is estimated to contribute about $20 \%$ of total fine particulate matter $\left(\mathrm{PM}_{2.5}\right)$ emissions in the United States (EPA, 2000). In 2006, a total of 96385 wildland fires were reported to burn 39958 square kilometers, $125 \%$ above the 10 -year average (NIFC, 2007). Among these forests, 11010 square kilometers were treated with prescribed fires, which is 1659 square kilometers above last year's total and is the second highest since 1998 (NIFC, 2007). Such large and increasing emission contributions are of concern to air quality managers, particularly in areas near or above the applicable air quality standards. For example, the prescribed fires on 28 February 2007 in Georgia and later the Georgia-Florida wildfires lasting from April through May severely impacted Atlanta, Georgia with thick wood smoke (Hu et al., 2008; Lee et al., 2008). During such events, hourly concentrations of $\mathrm{PM}_{2.5}$ increased by over $100 \mu \mathrm{g} \mathrm{m}^{-3}$.

Previous studies have shown that the major component of $\mathrm{PM}_{2.5}$ from forest burning events is organic carbon (OC), accounting for $30-70 \%$ of $\mathrm{PM}_{2.5}$ mass (Nopmongcol et al., 2007; Robinson et al., 2004; Ward et al., 2006). However, detailed data speciating $\mathrm{OC}$ in $\mathrm{PM}_{2.5}$ impacted by wildland fires is sparse, and even less data is available for aged plumes. During the 28 February 2007 event, OC reached $72 \mu \mathrm{g} \mathrm{m}^{-3}$ at 06:00 p.m. and contributed approximately $51 \%$ of the ambient $\mathrm{PM}_{2.5}$ in Atlanta, GA (Lee et al., 2008). This smoke

Published by Copernicus Publications on behalf of the European Geosciences Union. 
event provides an opportunity to characterize OC in such carbonaceous aerosols, further understand processes impacting the aging of fire plumes, and estimate the composition of prescribed fire-derived $\mathrm{PM}_{2.5}$ for source apportionment studies.

In this study, detailed GC/MS speciation of carbonaceous aerosols, along with receptor modeling, is used to quantify impacts from the biomass burning plume, although some other techniques can provide information about aerosol composition and source impacts as well. For example, aerosol mass spectrometer (AMS) is increasingly used to determine real-time size distribution and chemical composition of nonrefractory submicron inorganic and organic aerosols (Allan et al., 2003; Canagaratna et al., 2007; Jimenez et al., 2003). Recently, this method has been used to estimate source contributions from biomass burning through quantitatively characterizing hydrocarbon-like and oxygenated organic aerosols (Cottrell et al., 2008; DeCarlo et al., 2008; Zhang et al., 2005). GC/MS allows identification and quantification of hundreds of organic compounds from ambient $\mathrm{PM}_{2.5}$, including $n$-alkanes, hopanes, steranes, alkanoic acids, alkanedioic acids, PAHs, resin acids, and others (syringols, levoglucosan, cholesterol, 2-methyltetrols, etc.). Some of these compounds are reasonably unique tracers for certain sources and are widely used to track specific sources of carbonaceous aerosols. Similar sets of organic species have also been measured for source emissions. Together, they can be used to quantify source impacts on ambient $\mathrm{PM}_{2.5}$.

Source impacts from biomass burning are usually traced through a few organic tracers including levoglucosan, resin acids, syringols and retene. As a pyrolysis product of cellulose in wood biopolymers, levoglucosan has been considered a particularly useful molecular marker of biomass burning (Simoneit et al., 1999). With its large emission abundance and reasonable thermal stability in the atmosphere, levoglucosan is frequently used to assess air quality impacts from biomass burning (Fraser and Lakshmanan, 2000; Schauer and Cass, 2000). Resin acids are thermal alteration products of coniferous wood resins and emitted exclusively from softwood burning (various pines, firs, etc.) (Rogge et al., 1998; Simoneit et al., 1993; Standley and Simoneit, 1994). In contrast, hardwood combustion produces much higher quantities of syringols (Hawthorne et al., 1988, 1989). Although PAHs are emitted from multiple combustion processes of fuels (biomass, natural gas, diesel and gasoline) and ubiquitous in the atmosphere, retene, a thermal alteration of abietane compounds (resin diterpenoids), is considered as an organic tracer specific for coniferous wood burning (Ramdahl, 1983).

Other primary sources can be also linked to some specific organic tracers. Hopanes and steranes are emitted from both gasoline-powered vehicle and diesel-powered vehicle (Simoneit, 1985; Zielinska et al., 2004). They have been widely used as molecular markers of vehicular emissions in source apportionment of $\mathrm{PM}_{2.5}$ and $\mathrm{OC}$ (Fraser et al., 2003b; Schauer et al., 1996; Zheng et al., 2002, 2006, 2007). Cholesterol, found in animal fats and oils, is thought as an ex- cellent molecular marker of meat cooking emission (Rogge et al., 1991). Vegetative detritus emissions are characterized by high-molecular weight $n$-alkanes with pronounced odd over even carbon number predominance (Rogge et al., 1993a).

In addition to primary components of $\mathrm{PM}_{2.5}$, secondary organic aerosol (SOA) formation can result from gaseous emissions of isoprenoids (isoprene and monoterpene) (Claeys et al., 2004a; Kavouras et al., 1998). A few biogenic SOA species have been identified and quantified including 2methyltetrols (oxidation products of isoprene), pinonic acid and pinic acid (oxidation products of monoterpene) (Claeys et al., 2004a, b; Yu et al., 1999a, b). Although dicarboxylic acids (alkanedioic acids and dicarboxylic aromatic acids) can be emitted from various primary sources (mobile emission, meat cooking, etc.), previous studies suggested that atmospheric photochemical formation is probably the main source of these dicarboxylic acids (Fine et al., 2004b; Fraser et al., 2003a; Schauer et al., 2002).

Here, we collected $\mathrm{PM}_{2.5}$ filter samples before, during and after the 28 February 2007 prescribed fire episode impacting Atlanta, GA and analyzed organic composition of carbonaceous aerosols using GC/MS. We further capitalize on the quantified organic tracers to better understand the evolution of wood smoke from wildland fires.

\section{Method description}

\subsection{Ambient sampling}

Daily $\mathrm{PM}_{2.5}$ samples were collected on $47 \mathrm{~mm}$ quartz fiber filters with particulate composition monitors (PCM) at the Assessment of Spatial Aerosol Composition in Atlanta (ASACA) sites (Butler et al., 2003). These sites are located in the Atlanta metro area about $80 \mathrm{~km}$ downwind from the 28 February 2007 prescribed fires and were impacted directly by the smoke plume. The 24-h daily samples were analyzed for organic carbon/elemental carbon (OC/EC), metals and ions using thermal optical transmittance (TOT), X-ray fluorescence (XRF) and ion chromatography (IC), respectively. Details of ambient sampling, chemical measurements and particle compositions are described elsewhere (Baumann et al., 2003; Lee et al., 2005, 2008).

\subsection{Organic speciation}

Due to the low air volumes sampled, OC mass on a single PCM filter is usually not enough for organic tracer analysis. Therefore, three composite PCM samples (named "Before_Fire", "Event" and "After_Fire") were prepared as below. "Before_Fire" was composed of 6 PCM filters from three ASACA sites for the two days before the smoke day. "Event" was composed of 3 PCM filters collected at the same sites on 28 February, the day most directly impacted. "After-Fire" was composed of 7 PCM filters from the same sites 


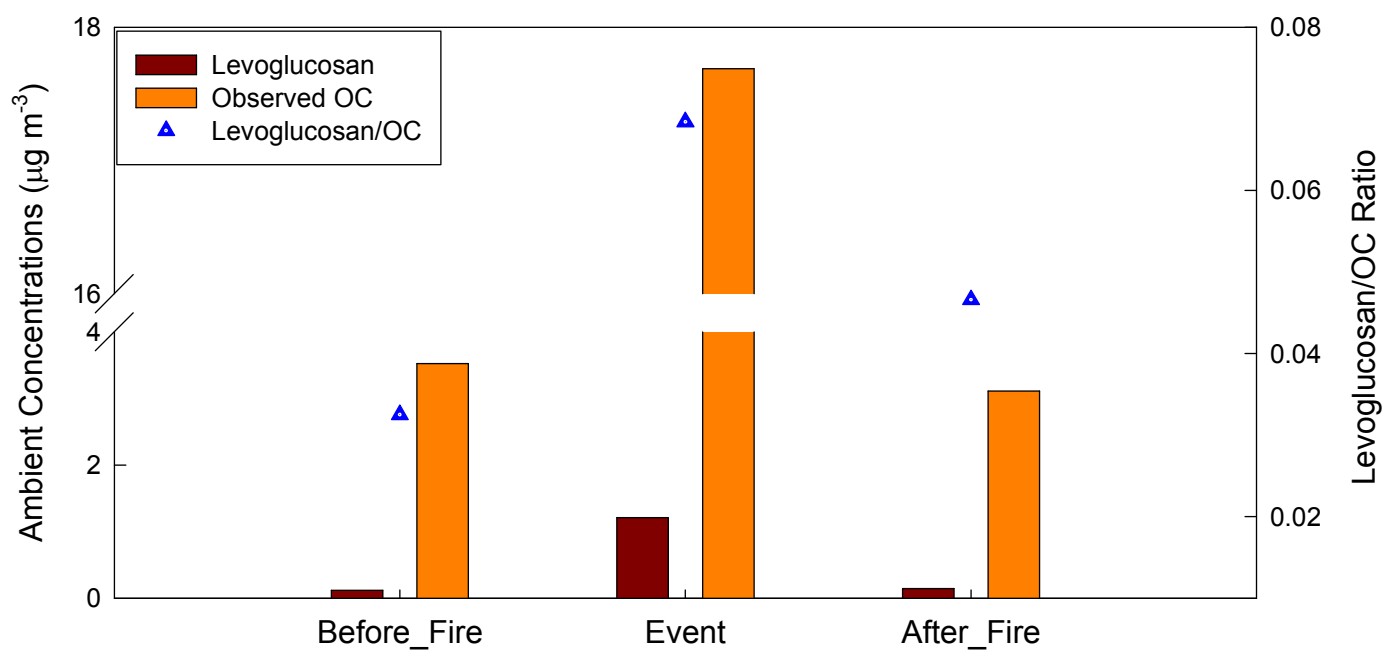

Fig. 1. 24-h average ambient concentrations of OC and levoglucosan observed before, during and after the event day at Atlanta area, GA.

within the three days after the smoke day. The three composite samples along with a composite field blank were analyzed for organic compounds in $\mathrm{PM}_{2.5}$ using a standardized method described elsewhere (Nolte et al., 2002; Zheng et al., 2002, 2006). Briefly, each filter composite was spiked with deuterated internal standard (IS) mixtures and then successively extracted using hexane and benzene/isopropanol $(2: 1, \mathrm{v} / \mathrm{v})$. After filtering, extracts were concentrated with rotary evaporation followed by blowdown under pure nitrogen. Half of each concentrated extract was then derivatized with diazomethane to convert organic acids to their methyl esters. These methylated extracts were analyzed by GC/MS along with authentic standards. To quantify polar organic compounds (levoglucosan, cholesterol and 2-methyltetrols), underivatized remains of concentrated extracts were silylated with BSTFA (N, O-bis(trimethylsilyl)acetamide) to convert polar compounds to trimethylsilyl (TMS) derivatives. After one hour reaction at $70^{\circ} \mathrm{C}$, these silylated extracts were analyzed using GC/MS along with authentic standards.

\section{Results and discussion}

Our results show that the observed 24-h average OC concentration jumped from 3.5 to $17.7 \mu \mathrm{g} \mathrm{m}^{-3}$ on the event day, accounting for more than $70 \%$ (when converted to organic matter by a factor of 1.5 (Lee et al., 2008)) of the total 24-h average $\mathrm{PM}_{2.5}$ mass of $37 \mu \mathrm{g} \mathrm{m}^{-3}$. Major sources of carbonaceous aerosols are traced using variations of their associated organic tracers.

\subsection{Organic tracers of biomass burning}

During the smoke, large increases were observed for biomass burning tracers (levoglucosan, resin acids, retene, etc.). Levoglucosan was detected in all ambient samples as the most abundant organic compound (Fig. 1). Before and after the smoke event, the observed levoglucosan concentrations were 114 and $145 \mathrm{ng} \mathrm{m}^{-3}$, respectively. On the event day, the levoglucosan concentration increased dramatically to $1210 \mathrm{ng} \mathrm{m}^{-3}$ and contributed $7 \%$ of the total OC, suggesting that the wood burning emission impact was 10 times higher on the event day than the non-smoke days. Along with levoglucosan, concentrations of resin acids also increased, especially dehydroabietic acid and 7-oxodehydroabietic acid, increasing to 42 and $19 \mathrm{ng} \mathrm{m}^{-3}$, approximately 9 and 23 times higher respectively than the levels before the burning day. Unlike levoglucosan, their ambient concentrations remained elevated after the fires (Fig. 2). To elucidate the processes occurring during transport, comparisons between wood burning source emissions and ambient data are conducted here. Ratios of major resin acids to levoglucosan were calculated and compared for both ambient data and a few source emissions from prominent softwood species in the southern United States (Table 1). In the softwood source emissions, abietic acid and dehydroabietic acid generally account for the majority of resin acids, about $58 \%$ and $32 \%$, respectively, on average, while 7-oxodehydroabietic acid is minor. However, dehydroabietic acid and 7-oxodehydroabietic acid constituted a major fraction of the observed resin acids, about $65 \%$ and $29 \%$ respectively, in the ambient sample impacted by the fires. This comparison provides evidence that dehydroabietic acid and 7-oxodehydroabietic acid are being formed from other resin acids (i.e. diterpenoids) during the $3-4 \mathrm{~h}$ (around $80 \mathrm{~km}$ travel distance) transport from the burning sites to the monitors. Note that further alterations of dehydroabietic acid and 7-oxodehydroabietic acid exist, leading to their ratios to levoglucosan being variable over time during transport. Previous studies have also proposed that dehydroabietic acid and 7-oxodehydroabietic acid can be formed through oxidation processes of other resin acids 

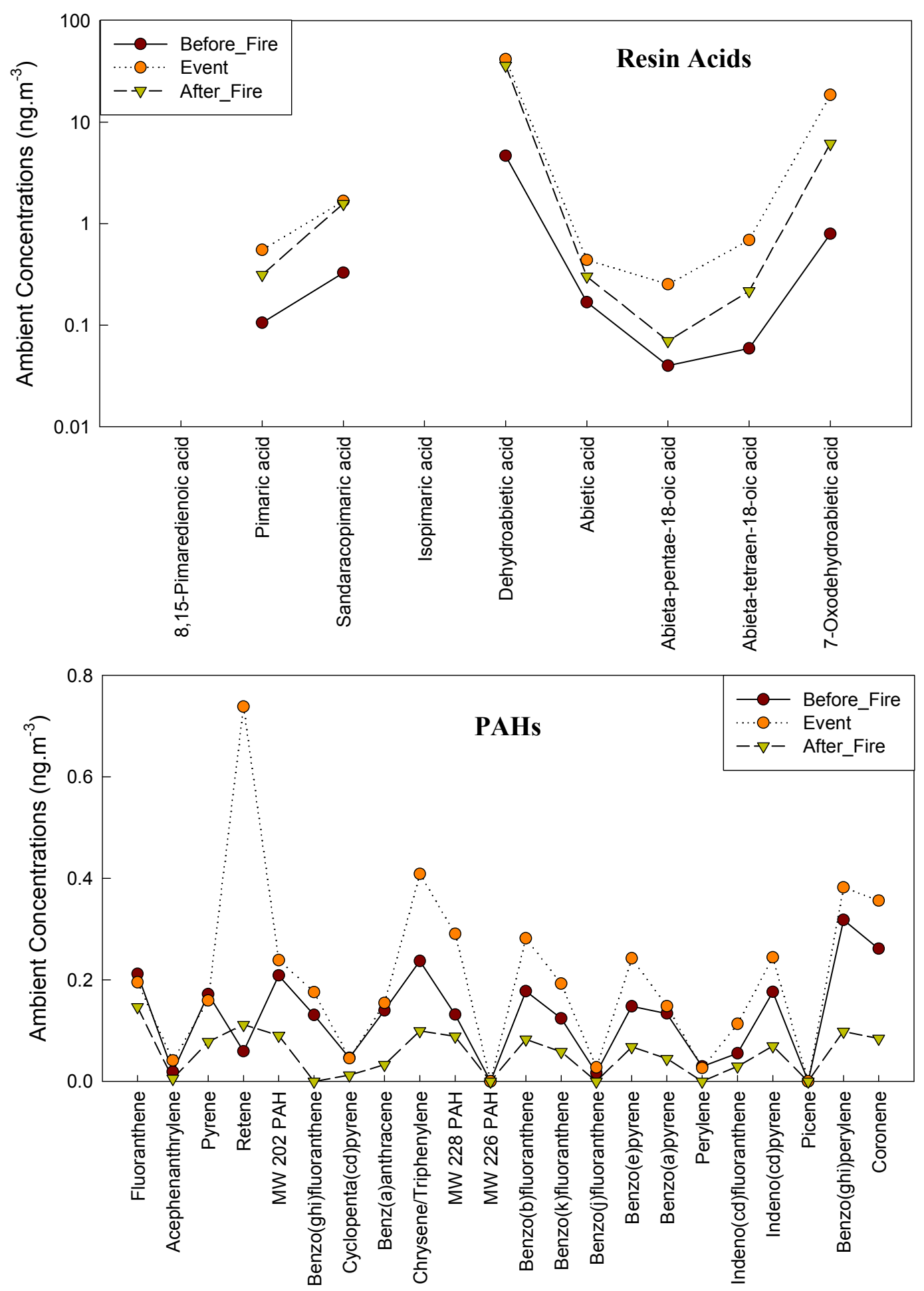

Fig. 2. 24-h average concentrations of resin acids and PAHs observed before, during and after the event day at Atlanta area, GA.

(i.e. abietic acids), resulting in accumulated concentrations in the atmosphere (Oros and Simoneit, 2001; Rogge et al., 1993b). Although most PAHs did not show significant elevation in ambient concentrations during the event day, retene, a potential softwood burning tracer, increased by around 12 and 7 times, respectively compared to before and after the fire, and predominated among all PAHs (Fig. 2). 
Table 1. Ratios of major resin acids to levoglucosan in source emissions and ambient samples.

\begin{tabular}{|c|c|c|c|c|c|c|c|c|}
\hline \multirow{2}{*}{ Compounds } & \multicolumn{5}{|c|}{ Softwood emissions } & \multicolumn{3}{|c|}{ Ambient samples } \\
\hline & $\begin{array}{l}\text { Loblolly } \\
\text { Pine }^{\mathrm{a}}\end{array}$ & $\begin{array}{l}\text { Slash } \\
\text { Pine }^{\mathrm{a}}\end{array}$ & $\begin{array}{l}\text { White } \\
\text { Pine }^{b}\end{array}$ & Hemlock $^{\mathrm{b}}$ & $\begin{array}{c}\text { Balsam } \\
\text { fir }^{\mathrm{b}}\end{array}$ & Before_Fire & Smoke & After_Fire \\
\hline Pimaric acid & 0.069 & 0.029 & 0.008 & 0.001 & 0.001 & 0.001 & 0.000 & 0.002 \\
\hline Sandaracopimaric acid & 0.013 & 0.011 & 0.026 & 0.002 & 0.001 & 0.003 & 0.001 & 0.011 \\
\hline Dehydroabietic acid & 0.339 & 0.141 & 0.149 & 0.017 & 0.028 & 0.041 & 0.034 & 0.248 \\
\hline Abietic acid & 0.801 & 0.056 & 0.391 & 0.021 & 0.240 & 0.001 & 0.000 & 0.002 \\
\hline Abieta- $6,8,11,13,15$-pentae-18-oic acid & 0.007 & 0.003 & 0.005 & 0.000 & 0.002 & 0.000 & 0.000 & 0.000 \\
\hline Abieta-8,11,13,15-tetraen-18-oic acid & 0.021 & 0.000 & 0.010 & 0.001 & 0.003 & 0.001 & 0.001 & 0.001 \\
\hline 7-Oxodehydroabietic acid & 0.009 & 0.004 & 0.005 & 0.001 & 0.000 & 0.007 & 0.015 & 0.042 \\
\hline
\end{tabular}

${ }^{\mathrm{a}}$ softwood species tested by Fine et al. (2002); ${ }^{\mathrm{b}}$ softwood species tested by Fine et al. (2001).

$n$-alkanes and $n$-alkanoic acids identified in this study ranged from $\mathrm{C}_{17}$ to $\mathrm{C}_{36}$ and from $\mathrm{C}_{14}$ to $\mathrm{C}_{30}$, respectively (Fig. 3). Generally, $n$-alkanes are associated with plant wax and fossil fuel contributions, depending on carbon numbers. To approximately compare source impacts from plant wax versus fossil fuel combustion, the carbon preference index (CPI) measuring carbon number predominance in homologous compound series is calculated (Mazurek and Simoneit, 1984; Oros et al., 2006). In the samples before and after the fire, $n$-alkanes only show a slight odd carbon number predominance with CPIs of 1.4 and 1.7 , respectively. However, $n$-alkanes exhibited distinctly strong odd carbon number predominance $\left(\mathrm{CPI}=3.1\right.$, carbon number maximum $\mathrm{C}_{\max }=29$ ) on the event day, reflecting a major contribution from plant waxes. Likewise, $n$-alkanoic acids had a strong even carbon number predominance on the event day $\left(\mathrm{CPI}=5.7, \mathrm{C}_{\max }=24\right)$. The concentration of even-over-odd carbon number series on the event day was $50 \mathrm{ng} \mathrm{m}^{-3}$, much larger than those before and after the event ( 12 and $10 \mathrm{ng} \mathrm{m}^{-3}$, respectively). Thus, a dominant contribution from plant waxes is suggested. These compounds are considered natural products of epicuticular waxes and internal lipid substances in leaf surfaces and emitted as vegetative detritus or through direct thermal volatilization (Rogge et al., 1993a; Simoneit, 2002). Higher leaf temperatures presumably lead to volatilization of these high-molecular weight organic compounds, which can then condense into the particle phase in the atmosphere. This result indicates that such waxes are not unique tracers for vegetative detritus when wildland fires also significantly impact air quality.

\subsection{Other primary organic tracers}

Non-biomass organic molecular markers were also analyzed as indicators of other major primary sources. Vehicular engine exhaust and meat cooking are the two other major sources of primary organic carbon in the Atlanta urban area (Lee et al., 2007; Liu et al., 2005; Marmur et al., 2005; Zheng et al., 2007). The before, during and after concen- trations of hopanes and steranes, both organic markers for internal combustion engine emissions, did not show significant variation, i.e. $1.7,1.7$ and $1.0 \mathrm{ng} \mathrm{m}^{-3}$ (Fig. 4). Cholesterol, an organic tracer of meat cooking, did not exhibit major variation as well (Fig. 5). Both suggest that primary sources other than prescribed fire have similar influences on Atlanta, GA before, during and after the event day. This point has further foundation from prior studies, which have shown that there is a significant increase in OC within Atlanta compared with a more rural site (e.g. Yorkville, GA) by analyzing regional EC and OC levels from the Southeastern Aerosol Research and Characterization (SEARCH) network (Edgerton et al., 2005; Hansen et al., 2003; Zheng et al., 2006). Furthermore, the sampling sites used here are spread out around metro Atlanta and capture the urban mix of primary sources. By compositing the filters, the results are relatively insensitive to changes in wind direction. On the other hand, very large increases in continuous $\mathrm{PM}_{2.5}$ and $\mathrm{OC}$ values were observed when the plume, which originated in a rural area, hit the urban monitors in Atlanta (Lee et al., 2008). These increases are consistent with those increases measured on the filters, and overwhelmed the background in this area. On the event day, $\mathrm{PM}_{2.5}$ increased by $23.9 \mu \mathrm{g} \mathrm{m}^{-3}$ (over $60 \%$ ) while OC increased by $14.2 \mu \mathrm{g} \mathrm{m}^{-3}$ (over $80 \%$ ). Biomass burning-related organic tracers (levoglucosan, resin acids and retene) increased by 7-23 times. In addition, Community Multi-scale Air Quality (CMAQ) modeling showed that the timing of the increase in OC is consistent with when the prescribed fire plume impacted Atlanta (Hu et al., 2008). These points strongly support that vehicular sources and meat cooking emissions are not responsible for the large increase in $\mathrm{PM}_{2.5}$ and $\mathrm{OC}$ on the event day, and that the greatly increased carbonaceous aerosol concentrations during the smoke episode are from prescribed fires. Source apportionment results calculated using organic molecular marker-based chemical mass balance (CMB-MM) model also indicate significant increases of prescribed burning emissions on the event day, but not for other 

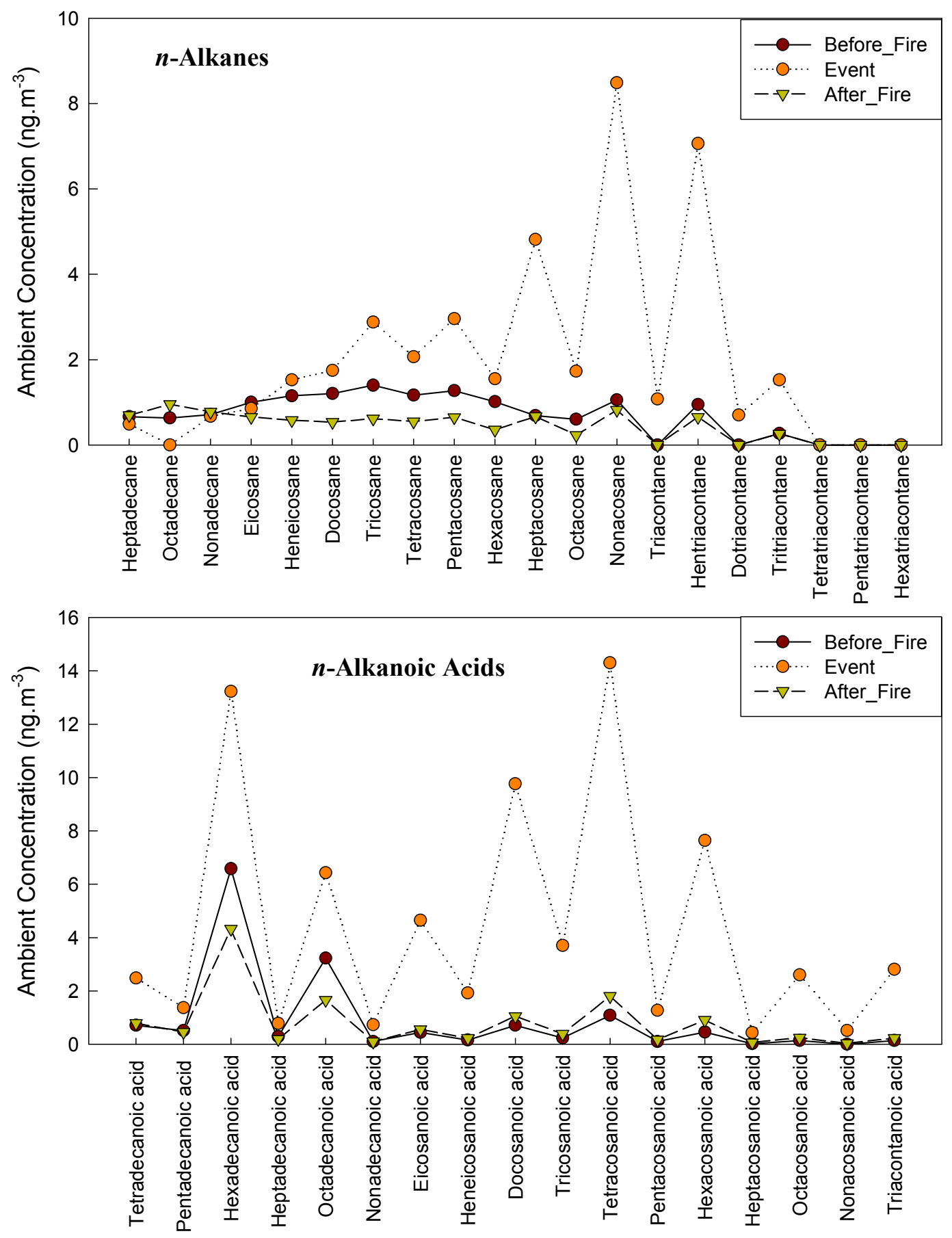

Fig. 3. 24-h average concentrations of $n$-alkanes and $n$-alkanoic acids observed before, during and after the event day at Atlanta area, GA.

major primary sources (i.e. vehicular source and meat cooking) (Lee et al., 2008). Moreover, about $43 \%$ of the total observed OC can not be explained by primary source contributions, suggesting that secondary organic aerosol (SOA) is also a significant contributor to the increased OC.

\subsection{Secondary organic tracers}

Our results for secondary organic tracers indicate that additional biogenic SOA were formed during the 28 February 2007 fire episode. 2-methyltetrols, secondary organic products of isoprene, were detected only on the smoke plume day with a concentration of $0.8 \mathrm{ng} \mathrm{m}^{-3}$ (Fig. 5). Pinonic acid 

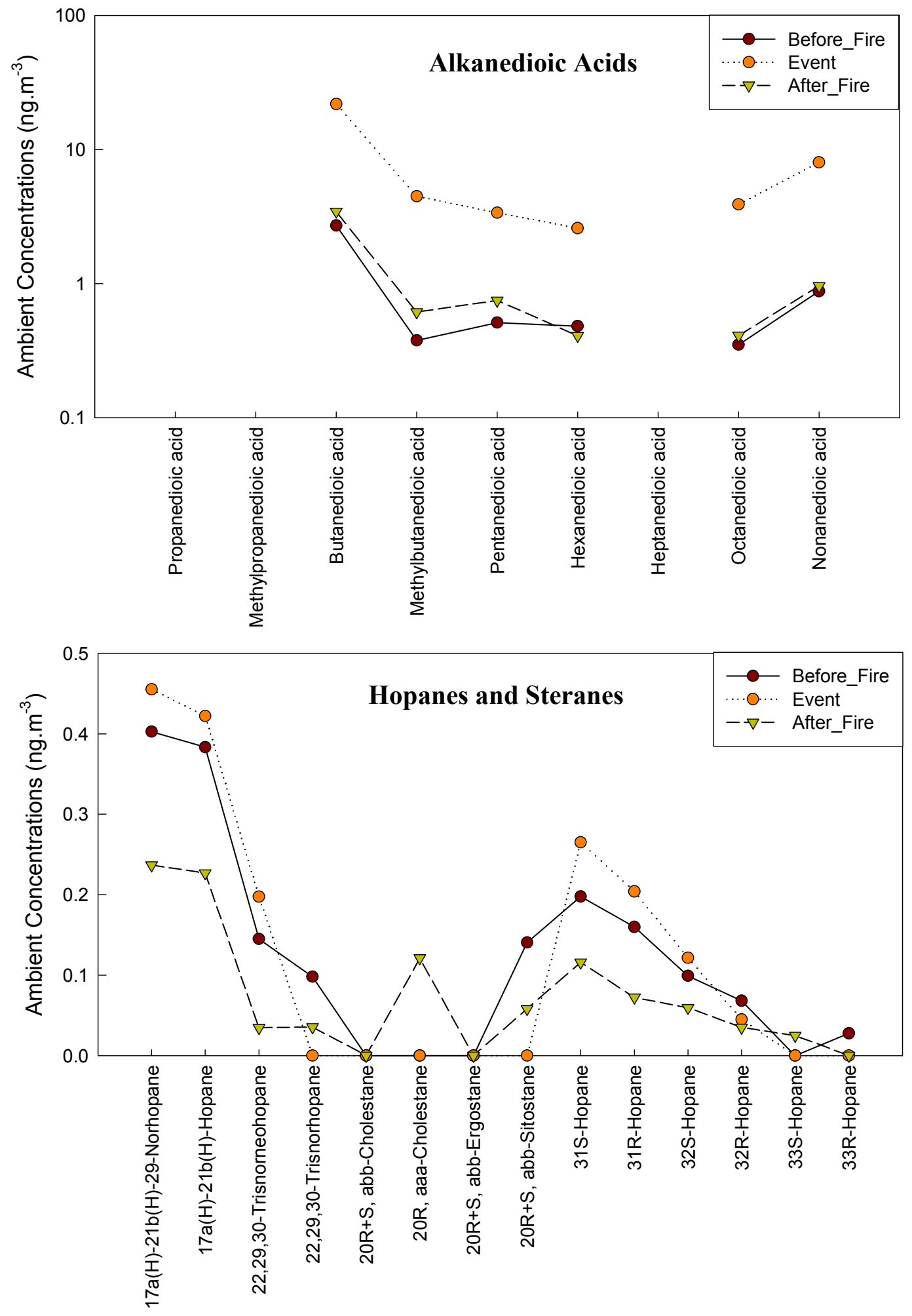

Fig. 4. 24-h average concentrations of alkanedioic acids, hopanes and steranes observed before, during and after the event day at Atlanta area, GA. 


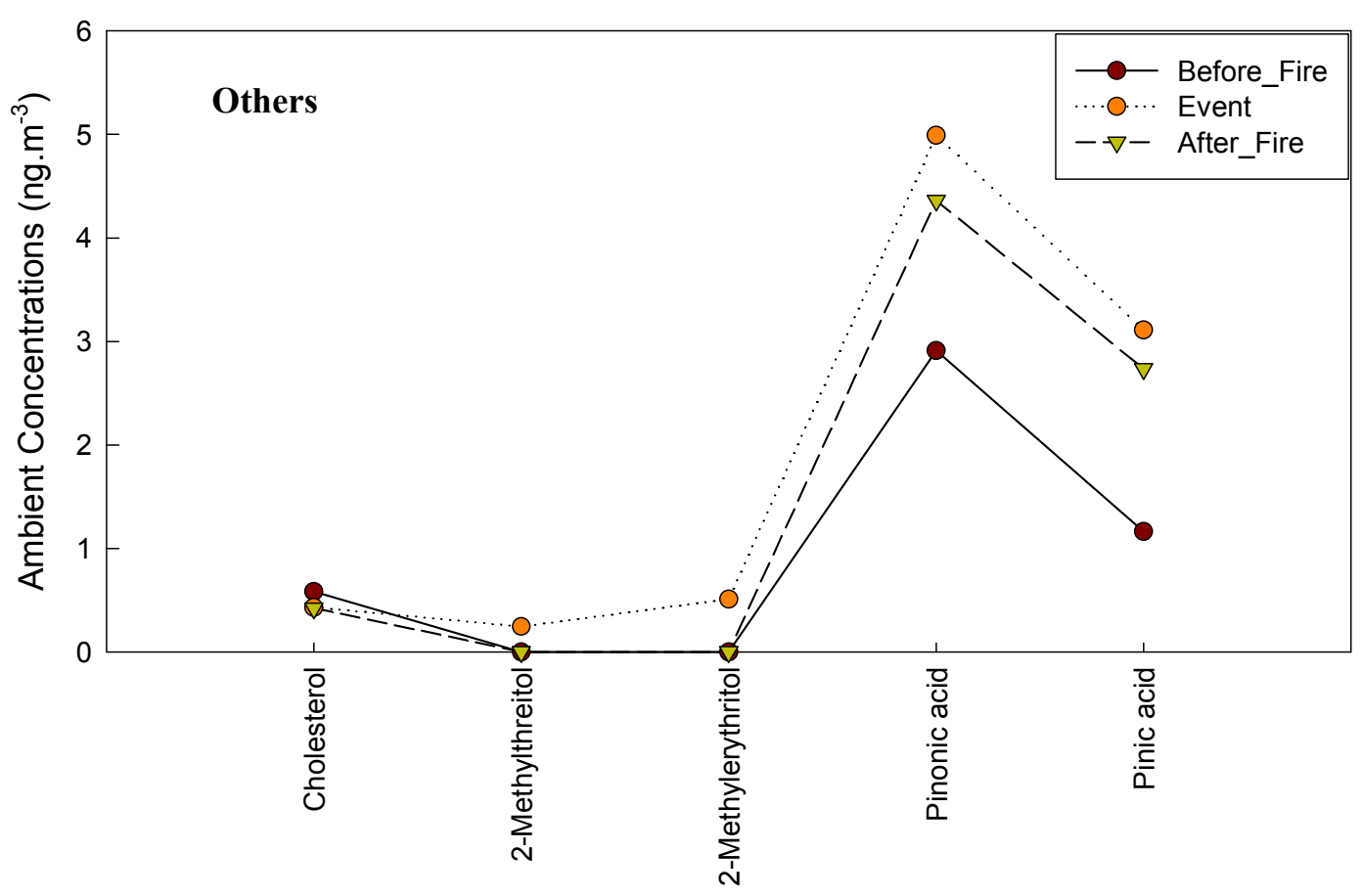

Fig. 5. 24-h average concentrations of other compounds (cholesterol, 2-methyltetrols, pinonic acid and pinic acid) observed before, during and after the event day at Atlanta area, GA.

and pinic acid, photo-oxidation products of monoterpenes, increased from 2.9 and $1.2 \mathrm{ng} \mathrm{m}^{-3}$ to 5.0 and $3.1 \mathrm{ng} \mathrm{m}^{-3}$, respectively, from the day prior to the fire through the smoke day (Fig. 5). Additionally, elevated dicarboxylic acids (alkanedioic acids and dicarboxylic aromatic acids) provided supportive evidence of increased SOA formation in the atmosphere. They are further considered here products of biogenic emissions enhanced by the fire since significant increases were not found in anthropogenic emissions (i.e. vehicular source and meat cooking). The sums of dicarboxylic acids were 7.5, 51, $8.4 \mathrm{ng} \mathrm{m}^{-3}$ before, during and after the event, respectively. There are three possible hypotheses relating to the large increases in these dicarboxylic acids. The most direct one is that precursors of these compounds are associated with prescribed fire emissions. As stated previously, emissions of biogenic VOC and SVOC (isoprenes, terpenes, sesquiterpenes, alcohols, esters, carbonyls, acids, etc.) would be enhanced by either wood combustion process or increasing leaf temperature. Emissions of isoprenoids (isoprene and monoterpene) have been observed to be higher during forest fires due to increased temperatures (Alessio et al., 2004). A previous study also suggests that leaf temperatures rising from 25 to $35^{\circ} \mathrm{C}$ would increase biogenic VOC and SVOC emissions by 4 and 1.5 times from isoprene-emitting deciduous trees and terpene-emitting conifers, respectively (Lamb et al., 1987). The second hypothesis is that the dramatic increase in OC mass can enhance formation of SOA due to increased partitioning of these diacids to the particle phase.
However, unless there is a significant chemical affinity between OC and the compounds, such a shift is not expected to be so large (less than 10\% of enhancement in SOA) (Nopmongcol et al., 2007; Odum et al., 1996). The third hypothesis is that enhanced photo-oxidation occurred. The observed increase of ozone in the plume is indicative that this effect might exist, but would be limited since ozone increased about $50 \%$ (from around 60 to $90 \mathrm{ppb}$ ), significantly less than the increase in dicarboxylic acids ( 8 times higher). Therefore, among the three hypotheses above, the evidence strongly supports that biomass burning is a major contributor to precursors of dicarboxylic acids. Results of air quality modeling and measurement of water soluble organic carbon (WSOC) provide further supporting evidence (Hu et al., 2008; Lee et al., 2008).

\subsection{Source profiles for an aged plume}

Capturing the fire event provides information to assess the source composition profiles of an aged prescribed fire plume. The above discussions indicate that the large increases in $\mathrm{PM}_{2.5}$, OC and associated chemical species on the event day are a direct contribution from prescribed fire emissions. From this result, associated aged source profiles can be derived. Here, two approximate source composition profiles were developed for the aged biomass burning plume by considering differences between the before_event day (non-fire event impacted) and the event day, designated "aged_plume 
Table 2. Source composition profiles from the aged plume on the event and the previous prescribed burning emission (ng/ $\mu \mathrm{g} \mathrm{PM}_{2.5}$ ).

\begin{tabular}{|c|c|c|c|c|c|c|c|}
\hline Compound & $\begin{array}{l}\text { Aged plume } \\
\text { Fraction }^{\mathrm{a}} \pm \text { std }^{\mathrm{e}}\end{array}$ & $\begin{array}{c}\operatorname{PPM}_{f c}{ }^{\mathrm{b}} \\
\text { Fraction } \pm \text { std }\end{array}$ & $\begin{array}{c}\text { Lee et al. }{ }^{\mathrm{c}} \\
\text { Fraction } \pm \text { std }\end{array}$ & Compound & $\begin{array}{l}\text { Aged plume }^{\mathrm{a}} \\
\text { Fraction } \pm \text { std }\end{array}$ & $\begin{array}{c}\operatorname{PPM}_{f c} \mathrm{~b} \\
\text { Fraction } \pm \text { std }\end{array}$ & $\begin{array}{c}\text { Lee et al. }{ }^{\mathrm{c}} \\
\text { Fraction } \pm \text { std }\end{array}$ \\
\hline \multicolumn{8}{|l|}{$n$-alkanes } \\
\hline Tetracosane & $0.038 \pm 0.021$ & $0.051 \pm 0.028$ & $0.084 \pm 0.053$ & Triacontane & $0.045 \pm 0.012$ & $0.061 \pm 0.016$ & $0.117 \pm 0.072$ \\
\hline Pentacosane & $0.071 \pm 0.029$ & $0.096 \pm 0.040$ & $0.151 \pm 0.095$ & Hentriacontane & $0.256 \pm 0.073$ & $0.347 \pm 0.102$ & $0.174 \pm 0.105$ \\
\hline Hexacosane & $0.023 \pm 0.016$ & $0.031 \pm 0.022$ & $0.137 \pm 0.091$ & Dotriacontane & $0.029 \pm 0.008$ & $0.040 \pm 0.011$ & $0.000 \pm 0.001$ \\
\hline Heptacosane & $0.173 \pm 0.050$ & $0.234 \pm 0.069$ & $0.151 \pm 0.114$ & Tritriacontane & $0.053 \pm 0.016$ & $0.071 \pm 0.022$ & $0.054 \pm 0.048$ \\
\hline Octacosane & $0.047 \pm 0.017$ & $0.064 \pm 0.024$ & $0.070 \pm 0.042$ & Tetratriacontane & $0.000 \pm 0.001$ & $0.000 \pm 0.001$ & $0.000 \pm 0.001$ \\
\hline Nonacosane & $0.311 \pm 0.088$ & $0.422 \pm 0.123$ & $0.486 \pm 0.295$ & & & & \\
\hline \multicolumn{8}{|l|}{ Branch-alkanes } \\
\hline iso-Nonacosane & $0.000 \pm 0.001$ & $0.000 \pm 0.001$ & $0.000 \pm 0.001$ & iso-Hentriacontane & $0.000 \pm 0.001$ & $0.000 \pm 0.001$ & $0.000 \pm 0.001$ \\
\hline anteiso-Triacontane & $0.000 \pm 0.001$ & $0.000 \pm 0.001$ & $0.000 \pm 0.001$ & & & & \\
\hline \multicolumn{8}{|l|}{ Hopanes } \\
\hline $\begin{array}{l}17 \alpha(\mathrm{H})-21 \beta(\mathrm{H})-29- \\
\text { Norhopane }\end{array}$ & $0.002 \pm 0.005$ & $0.003 \pm 0.007$ & $0.000 \pm 0.001$ & $\begin{array}{l}22 \mathrm{R}, 17 \alpha(\mathrm{H}), 21 \beta(\mathrm{H})- \\
\text { Homohopane }\end{array}$ & $0.002 \pm 0.002$ & $0.003 \pm 0.003$ & $0.000 \pm 0.001$ \\
\hline $\begin{array}{l}17 \alpha(\mathrm{H})-21 \beta(\mathrm{H})- \\
\text { Hopane }\end{array}$ & $0.002 \pm 0.005$ & $0.002 \pm 0.006$ & $0.000 \pm 0.001$ & $\begin{array}{l}22 \mathrm{~S}, 17 \alpha(\mathrm{H}), 21 \beta(\mathrm{H})- \\
\text { Bishomohopane }\end{array}$ & $0.001 \pm 0.001$ & $0.001 \pm 0.002$ & $0.000 \pm 0.001$ \\
\hline $\begin{array}{l}22,29,30- \\
\text { Trisnorneohopane }\end{array}$ & $0.002 \pm 0.002$ & $0.003 \pm 0.003$ & $0.000 \pm 0.001$ & $\begin{array}{l}22 \mathrm{R}, 17 \alpha(\mathrm{H}), 21 \beta(\mathrm{H})- \\
\text { Bishomohopane }\end{array}$ & $0.000 \pm 0.001$ & $0.000 \pm 0.001$ & $0.000 \pm 0.001$ \\
\hline $\begin{array}{l}22,29,30- \\
\text { Trisnorhopane }\end{array}$ & $0.000 \pm 0.001$ & $0.000 \pm 0.001$ & $0.000 \pm 0.001$ & $\begin{array}{l}22 \mathrm{~S}, 17 \alpha(\mathrm{H}), 21 \beta(\mathrm{H})- \\
\text { Trishomohopane }\end{array}$ & $0.000 \pm 0.001$ & $0.000 \pm 0.001$ & $0.000 \pm 0.001$ \\
\hline $\begin{array}{l}22 \mathrm{~S}, 17 \alpha(\mathrm{H}), 21 \beta(\mathrm{H})- \\
\text { Homohopane }\end{array}$ & $0.003 \pm 0.003$ & $0.004 \pm 0.004$ & $0.000 \pm 0.001$ & $\begin{array}{l}22 \mathrm{R}, 17 \alpha(\mathrm{H}), 21 \beta(\mathrm{H})- \\
\text { Trishomohopane }\end{array}$ & $0.000 \pm 0.001$ & $0.000 \pm 0.001$ & $0.000 \pm 0.001$ \\
\hline \multicolumn{8}{|l|}{ Steranes } \\
\hline $\begin{array}{l}20 \mathrm{~S}, \mathrm{R}- \\
5 \alpha(\mathrm{H}), 14 \beta(\mathrm{H}), 17 \beta(\mathrm{H})- \\
\text { Cholestanes }\end{array}$ & $0.000 \pm 0.001$ & $0.000 \pm 0.001$ & $0.000 \pm 0.001$ & $\begin{array}{l}20 \mathrm{~S}, \mathrm{R}- \\
5 \alpha(\mathrm{H}), 14 \beta(\mathrm{H}), 17 \beta(\mathrm{H}) \\
\text { Ergostanes }\end{array}$ & - & $0.000 \pm 0.001$ & $0.000 \pm 0.001$ \\
\hline $\begin{array}{l}20 \mathrm{R}- \\
5 \alpha(\mathrm{H}), 14 \alpha(\mathrm{H}), 17 \alpha(\mathrm{H})- \\
\text { Cholestane }\end{array}$ & $0.000 \pm 0.001$ & $0.000 \pm 0.001$ & $0.000 \pm 0.001$ & $\begin{array}{l}20 \mathrm{~S}, \mathrm{R}- \\
5 \alpha(\mathrm{H}), 14 \beta(\mathrm{H}), 17 \beta(\mathrm{H}) \\
\text { Sitostanes }\end{array}$ & $0.000 \pm 0.001$ & $0.000 \pm 0.001$ & $0.000 \pm 0.001$ \\
\hline \multicolumn{8}{|l|}{ PAHs } \\
\hline Fluoranthene & $0.000 \pm 0.001$ & $0.000 \pm 0.001$ & $0.054 \pm 0.031$ & Benzo(j)fluoranthene & $0.000 \pm 0.001$ & $0.001 \pm 0.001$ & $0.008 \pm 0.005$ \\
\hline Acephenanthrylene & $0.001 \pm 0.001$ & $0.001 \pm 0.001$ & $0.017 \pm 0.011$ & Benzo(e)pyrene & $0.004 \pm 0.002$ & $0.005 \pm 0.003$ & $0.030 \pm 0.017$ \\
\hline Pyrene & $0.000 \pm 0.001$ & $0.000 \pm 0.001$ & $0.065 \pm 0.036$ & Benzo(a)pyrene & $0.001 \pm 0.002$ & $0.001 \pm 0.002$ & $0.018 \pm 0.010$ \\
\hline Retene & $0.028 \pm 0.008$ & $0.039 \pm 0.011$ & $0.210 \pm 0.127$ & Perylene & $0.000 \pm 0.001$ & $0.000 \pm 0.001$ & $0.002 \pm 0.002$ \\
\hline Benzo(ghi)fluoranthene & $0.002 \pm 0.002$ & $0.003 \pm 0.003$ & $0.059 \pm 0.052$ & $\begin{array}{l}\text { Indeno(1,2,3- } \\
\text { cd)fluoranthene }\end{array}$ & $0.002 \pm 0.001$ & $0.003 \pm 0.002$ & $0.000 \pm 0.001$ \\
\hline Cyclopenta(cd)pyrene & $0.000 \pm 0.001$ & $0.000 \pm 0.001$ & $0.174 \pm 0.106$ & $\begin{array}{l}\text { Indeno(1,2,3- } \\
\text { cd)pyrene }\end{array}$ & $0.003 \pm 0.003$ & $0.004 \pm 0.003$ & $0.044 \pm 0.027$ \\
\hline Benz(a)anthracene & $0.001 \pm 0.002$ & $0.001 \pm 0.002$ & $0.048 \pm 0.027$ & Picene & $0.000 \pm 0.001$ & $0.000 \pm 0.001$ & $0.000 \pm 0.001$ \\
\hline Chrysene/Triphenylene & $0.007 \pm 0.004$ & $0.010 \pm 0.006$ & $0.059 \pm 0.033$ & Benzo(ghi)perylene & $0.003 \pm 0.004$ & $0.004 \pm 0.006$ & $0.022 \pm 0.012$ \\
\hline
\end{tabular}

profile" and "primary_plume profile". "Aged_plume profile" is constituted by fractions of individual chemical species (increased concentrations) in the total increased (fire-caused total) $\mathrm{PM}_{2.5}$ mass, i.e. $23.9 \mu \mathrm{g} \mathrm{m}^{-3}$, on the event day (Table 2). This profile contains chemical compositions of the aged plume, but is not the primary $\mathrm{PM}_{2.5}$ source profile due to large quantities of SOA in aerosol from the fire emissions. "Primary_plume profile" is then calculated using fractions of individual chemical species (increased concentrations) in the fire-caused primary $\mathrm{PM}_{2.5}$ mass where the esti- mated fire-caused secondary organic carbon (SOC) was subtracted from the fire-caused total $\mathrm{PM}_{2.5}$ mass on the event day (Table 2). The fire-caused SOC on the event was estimated based on the CMB-MM modeling results and measured EC/OC ratios. Briefly, the CMB-MM apportionment results indicate that prescribed fires contributed approximately 1.1 and $8.7 \mu \mathrm{g} \mathrm{m}^{-3}$ to the total primary OC before and on the event day, respectively (Lee et al., 2008). The difference, $7.6 \mu \mathrm{g} \mathrm{m}^{-3}$, is attributed to the plumes. Results here find that the total, primary plus secondary, impact of the 
Table 2. Continued.

\begin{tabular}{|c|c|c|c|c|c|c|c|}
\hline Compound & $\begin{array}{l}\text { Aged plume } \\
\text { Fraction }^{\mathrm{d}} \pm \text { std }^{\mathrm{e}}\end{array}$ & $\begin{array}{c}\operatorname{PPM}_{f c}{ }^{\mathrm{b}} \\
\text { Fraction } \pm \text { std }\end{array}$ & $\begin{array}{c}\text { Lee et al. }{ }^{\mathrm{c}} \\
\text { Fraction } \pm \text { std }\end{array}$ & Compound & $\begin{array}{l}\text { Aged Plume }^{a} \\
\text { Fraction } \pm \text { std }\end{array}$ & $\begin{array}{c}\operatorname{PPM}_{f c}{ }^{\mathrm{b}} \\
\text { Fraction } \pm \text { std }\end{array}$ & $\begin{array}{c}\text { Lee et al. }{ }^{\mathrm{c}} \\
\text { Fraction } \pm \text { std }\end{array}$ \\
\hline \multicolumn{8}{|l|}{ PAHs } \\
\hline $\begin{array}{l}\text { Benzo(b)fluoranthene } \\
\text { Benzo(k)fluoranthene }\end{array}$ & $\begin{array}{l}0.004 \pm 0.003 \\
0.003 \pm 0.002\end{array}$ & $\begin{array}{l}0.006 \pm 0.004 \\
0.004 \pm 0.003\end{array}$ & $\begin{array}{l}0.030 \pm 0.017 \\
0.025 \pm 0.014\end{array}$ & Coronene & $0.004 \pm 0.004$ & $0.005 \pm 0.005$ & $0.004 \pm 0.003$ \\
\hline \multicolumn{8}{|l|}{ Resin acids } \\
\hline $\begin{array}{l}\text { 8,15-Pimaredienoic } \\
\text { acid }\end{array}$ & $0.000 \pm 0.001$ & $0.000 \pm 0.001$ & $0.000 \pm 0.001$ & Abietic acid & $0.011 \pm 0.004$ & $0.015 \pm 0.006$ & $0.000 \pm 0.001$ \\
\hline Pimaric acid & $0.019 \pm 0.006$ & $0.025 \pm 0.008$ & $1.486 \pm 0.826$ & $\begin{array}{l}\text { Abieta- } \\
6,8,11,13,15- \\
\text { pentae-18-oic } \\
\text { acid }\end{array}$ & $0.009 \pm 0.003$ & $0.012 \pm 0.004$ & $0.000 \pm 0.001$ \\
\hline $\begin{array}{l}\text { Sandaracopimaric } \\
\text { acid }\end{array}$ & $0.056 \pm 0.017$ & $0.076 \pm 0.024$ & $0.000 \pm 0.001$ & $\begin{array}{l}\text { Abieta- } 8,11,13,15- \\
\text { tetraen-18-oic } \\
\text { acid }\end{array}$ & $0.026 \pm 0.007$ & $0.036 \pm 0.010$ & $0.000 \pm 0.001$ \\
\hline Isopimaric acid & $0.000 \pm 0.001$ & $0.000 \pm 0.001$ & $1.783 \pm 0.999$ & $\begin{array}{l}7- \\
\text { Oxodehydroabietic } \\
\text { acid }\end{array}$ & $0.743 \pm 0.198$ & $1.006 \pm 0.277$ & $0.000 \pm 0.001$ \\
\hline Dehydroabietic acid & $1.546 \pm 0.433$ & $2.092 \pm 0.605$ & $20.07 \pm 11.45$ & & & & \\
\hline \multicolumn{8}{|l|}{ Aromatic acids } \\
\hline $\begin{array}{l}1,2- \\
\text { Benzenedicarboxylic } \\
\text { acid } \\
1,4- \\
\text { Benzenedicarboxylic } \\
\text { acid }\end{array}$ & $0.119 \pm 0.036$ & $0.160 \pm 0.050$ & $0.009 \pm 0.006$ & $\begin{array}{l}1,3- \\
\text { Benzenedicarboxylic } \\
\text { acid }\end{array}$ & $0.029 \pm 0.011$ & $0.039 \pm 0.015$ & $0.000 \pm 0.001$ \\
\hline \multicolumn{8}{|l|}{ Alkanoic acids } \\
\hline $\begin{array}{l}\text { Tetradecanoic acid } \\
\text { Pentadecanoic acid } \\
\text { Hexadecanoic acid } \\
\text { Heptadecanoic acid } \\
\text { Octadecanoic acid } \\
\text { Nonadecanoic acid } \\
\text { Eicosanoic acid } \\
\text { Heneicosanoic acid } \\
\text { Docosanoic acid }\end{array}$ & $\begin{array}{l}0.074 \pm 0.025 \\
0.036 \pm 0.014 \\
0.278 \pm 0.132 \\
0.021 \pm 0.008 \\
0.134 \pm 0.064 \\
0.026 \pm 0.008 \\
0.176 \pm 0.049 \\
0.074 \pm 0.020 \\
0.379 \pm 0.103\end{array}$ & $\begin{array}{l}0.100 \pm 0.034 \\
0.049 \pm 0.019 \\
0.377 \pm 0.181 \\
0.028 \pm 0.011 \\
0.182 \pm 0.088 \\
0.036 \pm 0.011 \\
0.238 \pm 0.068 \\
0.100 \pm 0.028 \\
0.514 \pm 0.144\end{array}$ & $\begin{array}{l}1.209 \pm 0.743 \\
0.384 \pm 0.245 \\
4.055 \pm 2.338 \\
0.149 \pm 0.091 \\
1.351 \pm 0.811 \\
0.294 \pm 0.187 \\
0.720 \pm 0.437 \\
0.174 \pm 0.101 \\
1.076 \pm 0.638\end{array}$ & $\begin{array}{l}\text { Tricosanoic acid } \\
\text { Tetracosanoic acid } \\
\text { Pentacosanoic acid } \\
\text { Hexacosanoic acid } \\
\text { Heptacosanoic acid } \\
\text { Octacosanoic acid } \\
\text { Nonacosanoic acid } \\
\text { Triacontanoic acid }\end{array}$ & $\begin{array}{l}0.145 \pm 0.039 \\
0.554 \pm 0.151 \\
0.049 \pm 0.013 \\
0.301 \pm 0.081 \\
0.017 \pm 0.005 \\
0.103 \pm 0.028 \\
0.022 \pm 0.006 \\
0.112 \pm 0.030\end{array}$ & $\begin{array}{l}0.196 \pm 0.055 \\
0.750 \pm 0.211 \\
0.066 \pm 0.019 \\
0.408 \pm 0.114 \\
0.023 \pm 0.006 \\
0.140 \pm 0.039 \\
0.029 \pm 0.008 \\
0.152 \pm 0.042\end{array}$ & $\begin{array}{l}0.394 \pm 0.227 \\
2.984 \pm 1.740 \\
0.231 \pm 0.133 \\
2.212 \pm 1.282 \\
0.085 \pm 0.051 \\
0.595 \pm 0.350 \\
0.101 \pm 0.065 \\
0.484 \pm 0.314\end{array}$ \\
\hline \multicolumn{8}{|l|}{ Alkenoic acids } \\
\hline $\begin{array}{l}9,12- \\
\text { Octadecanedienoic } \\
\text { acid }\end{array}$ & $\begin{array}{l}0.000 \pm 0.001 \\
0.000 \pm 0.001\end{array}$ & $\begin{array}{l}0.000 \pm 0.001 \\
0.000 \pm 0.001\end{array}$ & $\begin{array}{l}0.306 \pm 0.227 \\
1.357 \pm 0.921\end{array}$ & $\begin{array}{l}\text { 9-Octadecenoic } \\
\text { acid }\end{array}$ & $0.000 \pm 0.001$ & $0.000 \pm 0.001$ & $1.469 \pm 0.881$ \\
\hline \multicolumn{8}{|l|}{ Alkanedioic acids } \\
\hline $\begin{array}{l}\text { Propanedioic acid } \\
\text { Methylpropanedioic } \\
\text { acid } \\
\text { Butanedioic acid }\end{array}$ & $\begin{array}{l}0.000 \pm 0.001 \\
0.000 \pm 0.001\end{array}$ & $\begin{array}{l}0.000 \pm 0.001 \\
0.000 \pm 0.001\end{array}$ & $\begin{array}{l}0.000 \pm 0.001 \\
0.000 \pm 0.001 \\
0.239+0.153\end{array}$ & $\begin{array}{l}\text { Hexanedioic acid } \\
\text { Heptanedioic acid }\end{array}$ & $\begin{array}{l}0.088 \pm 0.026 \\
0.000 \pm 0.001\end{array}$ & $\begin{array}{l}0.120 \pm 0.037 \\
0.000 \pm 0.001\end{array}$ & $\begin{array}{l}0.016 \pm 0.013 \\
0.018 \pm 0.016\end{array}$ \\
\hline Butanedioic acid & $0.801 \pm 0.227$ & $1.084 \pm 0.317$ & $0.239 \pm 0.153$ & Octanedioic acid & $0.149 \pm 0.041$ & $0.201 \pm 0.057$ & $0.036 \pm 0.028$ \\
\hline
\end{tabular}

plumes on $\mathrm{OC}$ is $14.2 \mu \mathrm{g} \mathrm{m}^{-3}$, suggesting that $6.6 \mu \mathrm{g} \mathrm{m}^{-3}$ (47\% of the fire-caused total OC) comes from enhanced SOC. A comparable SOC fraction in the fire-caused total OC was also estimated using the EC/OC ratio method. In the aged plume, the fire-caused EC/OC ratio is 0.039 while a value of 0.065 has been measured for prescribed burning emissions in Georgia (Lee et al., 2005). The lower EC/OC ratio suggests $\mathrm{SOA}$ formation in the aged plume. Using those 
Table 2. Continued.

\begin{tabular}{|c|c|c|c|c|c|c|c|}
\hline Compound & $\begin{array}{l}\text { Aged plume }^{\mathrm{a}} \\
\text { Fraction }^{\mathrm{d}} \pm \text { std }^{\mathrm{e}}\end{array}$ & $\begin{array}{c}\operatorname{PPM}_{f c}{ }^{\mathrm{b}} \\
\text { Fraction } \pm \text { std }\end{array}$ & $\begin{array}{c}\text { Lee et al. }{ }^{\mathrm{c}} \\
\text { Fraction } \pm \text { std }\end{array}$ & Compound & $\begin{array}{l}\text { Aged plume }^{a} \\
\text { Fraction } \pm \text { std }\end{array}$ & $\begin{array}{c}\operatorname{PPM}_{f c}{ }^{\mathrm{b}} \\
\text { Fraction } \pm \text { std }\end{array}$ & $\begin{array}{c}\text { Lee et al. }{ }^{\mathrm{c}} \\
\text { Fraction } \pm \text { std }\end{array}$ \\
\hline \multicolumn{8}{|l|}{ Alkanedioic acids } \\
\hline $\begin{array}{l}\text { Methylbutanedioic } \\
\text { acid }\end{array}$ & $0.172 \pm 0.047$ & $0.232 \pm 0.066$ & $0.000 \pm 0.001$ & Nonanedioic acid & $0.299 \pm 0.084$ & $0.404 \pm 0.117$ & $0.156 \pm 0.101$ \\
\hline Pentanedioic acid & $0.120 \pm 0.035$ & $0.162 \pm 0.048$ & $0.049 \pm 0.032$ & & & & \\
\hline \multicolumn{8}{|l|}{ Others } \\
\hline Nonanal & $0.013 \pm 0.009$ & $0.017 \pm 0.012$ & $0.000 \pm 0.001$ & $\begin{array}{l}\text { Benz(de)anthracen- } \\
\text { 7-one }\end{array}$ & $0.004 \pm 0.002$ & $0.005 \pm 0.003$ & $0.000 \pm 0.001$ \\
\hline Sinapyl aldehyde & $0.000 \pm 0.001$ & $0.000 \pm 0.001$ & $0.000 \pm 0.001$ & $\begin{array}{l}\text { 3,5-Dimethoxy-4- } \\
\text { hydroxyacetophenone }\end{array}$ & $0.028 \pm 0.007$ & $0.037 \pm 0.010$ & $0.000 \pm 0.001$ \\
\hline Acetonylsyringol & $0.058 \pm 0.018$ & $0.079 \pm 0.025$ & $0.000 \pm 0.001$ & Levoglucosan & $45.91 \pm 12.69$ & $62.15 \pm 17.75$ & $57.09 \pm 32.38$ \\
\hline Coniferyl aldehyde & $0.000 \pm 0.001$ & $0.000 \pm 0.001$ & $0.000 \pm 0.001$ & Cholesterol & $0.000 \pm 0.001$ & $0.000 \pm 0.001$ & $0.000 \pm 0.001$ \\
\hline Propionylsyringol & $0.000 \pm 0.001$ & $0.000 \pm 0.001$ & $0.000 \pm 0.001$ & & & & \\
\hline $\mathrm{OC}$ & $593.9 \pm 180.2$ & $450.2 \pm 250.6$ & $602.5 \pm 185.2$ & $\mathrm{Cl}^{-}$ & $0.44 \pm 0.09$ & $0.59 \pm 0.13$ & $5.27 \pm 2.89$ \\
\hline EC & $23.0 \pm 12.4$ & $31.1 \pm 17.0$ & $39.2 \pm 11.3$ & $\mathrm{NH}_{4}^{+}$ & $13.12 \pm 4.43$ & $17.76 \pm 6.13$ & $1.07 \pm 1.08$ \\
\hline $\mathrm{Al}$ & $0.000 \pm 0.001$ & $0.000 \pm 0.001$ & $0.229 \pm 0.426$ & $\mathrm{NO}_{3}^{-}$ & $19.31 \pm 5.18$ & $26.14 \pm 7.26$ & $4.40 \pm 2.99$ \\
\hline $\mathrm{Si}$ & $0.289 \pm 0.228$ & $0.391 \pm 0.309$ & $0.186 \pm 0.258$ & $\mathrm{SO}_{4}^{2-}$ & $13.80 \pm 8.57$ & $18.68 \pm 11.68$ & $2.45 \pm 1.12$ \\
\hline $\mathrm{K}^{+}$ & $2.23 \pm 0.50$ & $3.01 \pm 0.72$ & $6.49 \pm 4.35$ & & & & \\
\hline
\end{tabular}

a source composition profiles where individual chemical species are normalized to the fire-caused total $\mathrm{PM}_{2.5}$ mass on the event day;

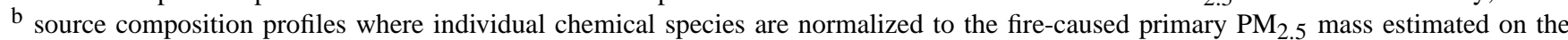
event day;

c source composition profiles from the prescribed burning emission in Georgia (Lee et al., 2005);

$\mathrm{d}$ fraction of chemical species in the associated $\mathrm{PM}_{2.5}$ mass $\left(\mathrm{ng} / \mu \mathrm{g} \mathrm{PM}_{2.5}\right)$;

e standard deviation.

ratios, SOC is calculated to account for $40 \%$ of the firecaused total OC. Averaging the two, $44 \%$ of fire-caused total OC is taken as SOC during the event, and the fire-caused primary $\mathrm{OC}\left(\mathrm{POC}_{f c}\right)$ is then estimated by:

$$
\begin{aligned}
\mathrm{POC}_{f c} & =\mathrm{OC}(\text { fire-caused }) \times\left(1-f_{\mathrm{SOC}}\right) \\
& =[\mathrm{OC}(\text { event })-\mathrm{OC}(\text { before-event })] \times\left(1-f_{\mathrm{SOC}}\right)
\end{aligned}
$$

where $f_{\mathrm{SOC}}$ is the estimated SOC fraction in the fire-caused total OC. Similarly, the amount of fire_caused primary $\mathrm{PM}_{2.5}$ $\left(\mathrm{PPM}_{f c}\right)$ is calculated as:

$$
\begin{aligned}
\mathrm{PPM}_{f c}= & {[\mathrm{PM}(\text { event })-\mathrm{PM}(\text { before-event })] } \\
& -\mathrm{OC}(\text { fire-caused }) \times f_{\text {SOC }}
\end{aligned}
$$

Finally, fractions of individual species $\left(f_{i}\right)$ in fire_caused primary $\mathrm{PM}_{2.5}$ are found as:

$f_{i}=\frac{C_{i} \text { (event) }-C_{i} \text { (before-event) }}{\operatorname{PPM}_{f c}}$

where $C_{i}$ is the ambient concentration of individual chemical species in $\mathrm{PM}_{2.5}$ that are viewed as being dominated by primary emissions. In addition, an overall uncertainty of each chemical species in the two plume source profiles was calculated by propagating uncertainties associated with the observed OC, estimated SOC fraction and measured chemical species (i.e. organic compounds, EC, ions and trace metals).
Our study indicates that the "primary_plume profile" derived from the fire event is comparable with the prescribed burning emission profile measured by Lee et al. (2005) for some organic compounds, but significantly different for others (Table 2 and Fig. 6). In the aged fire plume, levoglucosan accounts for $14 \%$ of primary OC, comparable to $9.5 \%$ in the profile of Lee et al. (2005). Most $n$-alkanes also show comparable levels for the two source profiles. Hopanes and steranes were not significant in either set. The ratio of watersoluble potassium $\left(\mathrm{K}^{+}\right) / \mathrm{OC}$ in the "primary_plume profile" is 0.0067 , lower than the values in Lee et al. (0.011) and in Fine et al. (0.012 on average), but comparable to the average ratio of 0.0058 from foliar fuel combustion (Fine et al., 2004a; Hays et al., 2002; Lee et al., 2005). However, significant differences were found for the fractions of PAHs, resin acids, $n$-alkanoic acid and dicarboxylic acids, suggesting aging of fire smoke after a 3-4 h travel distance. Lee et al. (2005) measured higher abundances for many PAHs and resin acids, implying direct combustion is the main contributor of these compounds and significant chemical alteration occurs during transport, especially for resin acids. In contrast, the aged plume has distinctly higher dicarboxylic acids (alkanedioic acids and dicarboxylic aromatic acids) fractions. Enhanced SOA formation in the atmosphere from the fire is suggested by these secondary indicators. The 


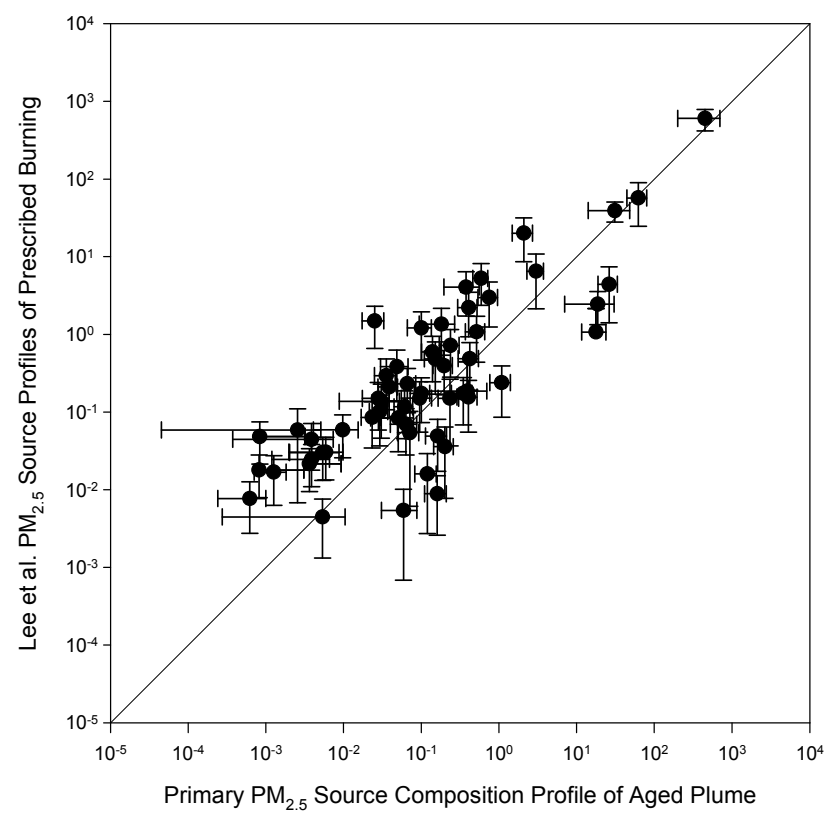

Fig. 6. Comparison between source composition profiles developed from the aged biomass burning plume on the event and the prescribed burning emission measured by Lee et al. (2005). The profiles are composed of individual species fractions, normalized to primary $\mathrm{PM}_{2.5}$ mass. A log-log scale is used.

profile comparison between prescribed fire source emission and aged plume is useful to understand evolution of wood smoke during transport and to assess the organic species applied in CMB-MM modeling. Impacts from aging process of smoke plume should be considered in source apportionment methodology using CMB model, i.e. selection of fitting species.

\section{Conclusions}

Large increases in $\mathrm{PM}_{2.5}$ and $\mathrm{OC}$ in Atlanta caused by an aged prescribed fire plume through direct burning emissions and formation of secondary organic aerosols was captured by a system of monitors. Organic tracers of biomass burning, levoglucosan, resin acids and retene, exhibited sharp increases in concentrations during the episode. Observed resin acids and retene indicated predominant softwood (conifers) burning. Increases in resin acids were accompanied by high levels of dehydroabietic acids and 7-oxodehydroabietic acids, mainly formed during transport. Carbon number predominance for $n$-alkanes (odd over even) and $n$-alkanoic acids (even over odd) suggested that emissions from heatexposed vegetation are important as one of major sources for increasing OC, especially secondary OC. Secondary organic tracers were observed with significantly higher ambient concentrations, providing further support for biogenic SOA formation. These data allow estimating source profiles for aged fire plumes, which can be used for improving source apportionment of wood burning by CMB modeling.

The supplementary material can be found at http://www.atmos-chem-phys.net/8/6381/2008/ acp-8-6381-2008-supplement.pdf.

Acknowledgements. This work was funded by the US Environmental Protection Agency STAR grants (R832159, R828976 and R831076). We would like to thank Georgia Power (Southern Company) for their support of work in Laboratory for Atmospheric Modeling, Diagnostics, and Analysis (LAMDA) at Georgia Institute of Technology in this study area. The authors also acknowledge the helpful forest information provided by Di Tian.

Edited by: A. Nenes

\section{References}

Alessio, G. A., De Lillis, M., Fanelli, M., Pinelli, P., and Loreto, F.: Direct and indirect impacts of fire on isoprenoid emissions from Mediterranean vegetation, Functional Ecology, 18, 357364, 2004.

Allan, J. D., Jimenez, J. L., Williams, P. I., Alfarra, M. R., Bower, K. N., Jayne, J. T., Coe, H., and Worsnop, D. R.: Quantitative sampling using an Aerodyne aerosol mass spectrometer: 1. Techniques of data interpretation and error analysis, J. Geophys. Res.Atmos., 108, 4090, doi:10.1029/2003jd001607, 2003.

Baumann, K., Ift, F., Zhao, J. Z., and Chameides, W. L.: Discrete measurements of reactive gases and fine particle mass and composition during the 1999 Atlanta Supersite Experiment, J. Geophys. Res.-Atmos., 108, 8416, doi:10.1029/2001jd001210, 2003.

Butler, A. J., Andrew, M. S., and Russell, A. G.: Daily sampling of PM2.5 in Atlanta: results of the first year of the assessment of spatial aerosol composition in Atlanta study, J. Geophys. Res.Atmos., 108, 8415, doi:10.1029/2002jd002234, 2003.

Canagaratna, M. R., Jayne, J. T., Jimenez, J. L., Allan, J. D., Alfarra, M. R., Zhang, Q., Onasch, T. B., Drewnick, F., Coe, H., Middlebrook, A., Delia, A., Williams, L. R., Trimborn, A. M., Northway, M. J., DeCarlo, P. F., Kolb, C. E., Davidovits, P., and Worsnop, D. R.: Chemical and microphysical characterization of ambient aerosols with the aerodyne aerosol mass spectrometer, Mass Spectrom. Rev., 26, 185-222, doi:10.1002/Mas.20115, 2007.

Claeys, M., Graham, B., Vas, G., Wang, W., Vermeylen, R., Pashynska, V., Cafmeyer, J., Guyon, P., Andreae, M. O., Artaxo, P., and Maenhaut, W.: Formation of secondary organic aerosols through photooxidation of isoprene, Science, 303, 1173-1176, 2004a.

Claeys, M., Wang, W., Ion, A. C., Kourtchev, I., Gelencser, A., and Maenhaut, W.: Formation of secondary organic aerosols from isoprene and its gas-phase oxidation products through reaction with hydrogen peroxide, Atmos. Environ., 38, 4093-4098, doi:10.1016/j.atmosenv.2004.06.001, 2004b.

Cottrell, L. D., Griffin, R. J., Jimenez, J. L., Zhang, Q., Ulbrich, I., Ziemba, L. D., Beckman, P. J., Sive, B. C., and Talbot, R. W.: Submicron particles at Thompson Farm during ICARTT measured using aerosol mass spectrometry, J. Geophys. Res.-Atmos., 113, D08212, doi:10.1029/2007jd009192, 2008.

DeCarlo, P. F., Dunlea, E. J., Kimmel, J. R., Aiken, A. C., Sueper, D., Crounse, J., Wennberg, P. O., Emmons, L., Shinozuka, Y., 
Clarke, A., Zhou, J., Tomlinson, J., Collins, D. R., Knapp, D., Weinheimer, A. J., Montzka, D. D., Campos, T., and Jimenez, J. L.: Fast airborne aerosol size and chemistry measurements above Mexico City and Central Mexico during the MILAGRO campaign, Atmos. Chem. Phys., 8, 4027-4048, 2008, http://www.atmos-chem-phys.net/8/4027/2008/.

EPA, US: National Air Pollutant Emission Trends 1900-1998, EPA 454/R-400-002, Office: Washington, D.C., 2000.

Fine, P. M., Cass, G. R., and Simoneit, B. R. T.: Chemical characterization of fine particle emissions from fireplace combustion of woods grown in the northeastern United States, Environ. Sci. Technol., 35, 2665-2675, 2001.

Fine, P. M., Cass, G. R., and Simoneit, B. R. T.: Chemical characterization of fine particle emissions from the fireplace combustion of woods grown in the southern United States, Environ. Sci. Technol., 36, 1442-1451, 2002.

Fine, P. M., Cass, G. R., and Simoneit, B. R. T.: Chemical characterization of fine particle emissions from the wood stove combustion of prevalent United States tree species, Environ. Eng. Sci., 21, 705-721, 2004a.

Fine, P. M., Chakrabarti, B., Krudysz, M., Schauer, J. J., and Sioutas, C.: Diurnal variations of individual organic compound constituents of ultrafine and accumulation mode particulate matter in the Los Angeles basin, Environ. Sci. Technol., 38, 12961304, 2004b.

Fraser, M. P. and Lakshmanan, K.: Using levoglucosan as a molecular marker for the long-range transport of biomass combustion aerosols, Environ. Sci. Technol., 34, 4560-4564, 2000.

Fraser, M. P., Cass, G. R., and Simoneit, B. R. T.: Air quality model evaluation data for organics. 6. C-3-C-24 organic acids, Environ. Sci. Technol., 37, 446-453, 2003a.

Fraser, M. P., Yue, Z. W., and Buzcu, B.: Source apportionment of fine particulate matter in Houston, TX, using organic molecular markers, Atmos. Environ., 37, 2117-2123, 2003b.

Hawthorne, S. B., Miller, D. J., Barkley, R. M., and Krieger, M. S.: Identification of Methoxylated Phenols as Candidate Tracers for Atmospheric Wood Smoke Pollution, Environ. Sci. Technol., 22, 1191-1196, 1988.

Hawthorne, S. B., Krieger, M. S., Miller, D. J., and Mathiason, M. B.: Collection and Quantitation of Methoxylated Phenol Tracers for Atmospheric-Pollution from Residential Wood Stoves, Environ. Sci. Technol., 23, 470-475, 1989.

Hays, M. D., Geron, C. D., Linna, K. J., Smith, N. D., and Schauer, J. J.: Speciation of gas-phase and fine particle emissions from burning of foliar fuels, Environ. Sci. Technol., 36, 2281-2295, 2002.

Hu, Y. T., Odman, M. T., Chang, M. E., Jackson, W., Lee, S., Edgerton, E. S., Baumann, K., and Russellt, A. G.: Simulation of air quality impacts from prescribed fires on an urban area, Environ. Sci. Technol., 42, 3676-3682, doi:10.1021/Es071703k, 2008.

Jimenez, J. L., Jayne, J. T., Shi, Q., Kolb, C. E., Worsnop, D. R., Yourshaw, I., Seinfeld, J. H., Flagan, R. C., Zhang, X. F., Smith, K. A., Morris, J. W., and Davidovits, P.: Ambient aerosol sampling using the Aerodyne Aerosol Mass Spectrometer, J. Geophys. Res.-Atmos., 108, 8425, doi:10.1029/2001jd001213, 2003.

Kavouras, I. G., Mihalopoulos, N., and Stephanou, E. G.: Formation of atmospheric particles from organic acids produced by forests, Nature, 395, 683-686, 1998.

Lamb, B., Guenther, A., Gay, D., and Westberg, H.: A National
Inventory of Biogenic Hydrocarbon Emissions, Atmos. Environ., 21, 1695-1705, 1987.

Lee, S., Baumann, K., Schauer, J. J., Sheesley, R. J., Naeher, L. P., Meinardi, S., Blake, D. R., Edgerton, E. S., Russell, A. G., and Clements, M.: Gaseous and particulate emissions from prescribed burning in Georgia, Environ. Sci. Technol., 39, 90499056, doi:10.1021/Es0515831, 2005.

Lee, S., Kim, H. K., Yan, B., Cobb, C. E., Hennigan, C., Nichols, S., Chamber, M., Edgerton, E. S., Jansen, J. J., Hu, Y. T., Zheng, M., Weber, R. J., and Russell, A. G.: Diagnosis of aged prescribed burning plumes impacting an urban area, Environ. Sci. Technol., 42, 1438-1444, doi:10.1021/Es7023059, 2008.

National Interagency Fire Center: fire information - wildland fire statistics, available at: http://www.nifc.gov/fire_info/prescribed fires.htm, access: August 2007.

Nolte, C. G., Schauer, J. J., Cass, G. R., and Simoneit, B. R. T.: Trimethylsilyl derivatives of organic compounds in source samples and in atmospheric fine particulate matter, Environ. Sci Technol., 36, 4273-4281, 2002.

Nopmongcol, U., Khamwichit, W., Fraser, M. P., and Allen, D. T.: Estimates of heterogeneous formation of secondary organic aerosol during a wood smoke episode in Houston, Texas, Atmos. Environ., 41, 3057-3070, 2007.

Odum, J. R., Hoffmann, T., Bowman, F., Collins, D., Flagan, R. C., and Seinfeld, J. H.: Gas/particle partitioning and secondary organic aerosol yields, Environ. Sci. Technol., 30, 2580-2585, 1996.

Oros, D. R. and Simoneit, B. R. T.: Identification and emission factors of molecular tracers in organic aerosols from biomass burning Part 1. Temperate climate conifers, Appl. Geochem., 16, 1513-1544, 2001.

Oros, D. R., bin Abas, M. R., Omar, N. Y. M. J., Rahman, N. A., and Simoneit, B. R. T.: Identification and emission factors of molecular tracers in organic aerosols from biomass burning: Part 3. Grasses, Appl. Geochem., 21, 919-940, 2006.

Ramdahl, T.: Retene - a Molecular Marker of Wood Combustion in Ambient Air, Nature, 306, 580-583, 1983.

Robinson, M. S., Chavez, J., Velazquez, S., and Jayanty, R. K. M.: Chemical speciation of PM2.5 fires of the coconino national collected during prescribed forest near Flagstaff, Arizona, J. Air Waste Manage. Assoc., 54, 1112-1123, 2004.

Rogge, W. F., Hildemann, L. M., Mazurek, M. A., Cass, G. R., and Simonelt, B. R. T.: Sources of Fine Organic Aerosol .1. Charbroilers and Meat Cooking Operations, Environ. Sci. Technol., 25, 1112-1125, 1991.

Rogge, W. F., Hildemann, L. M., Mazurek, M. A., Cass, G. R., and Simoneit, B. R. T.: Sources of Fine Organic Aerosol .4. Particulate Abrasion Products from Leaf Surfaces of Urban Plants, Environ. Sci. Technol., 27, 2700-2711, 1993a.

Rogge, W. F., Mazurek, M. A., Hildemann, L. M., Cass, G. R., and Simoneit, B. R. T.: Quantification of Urban Organic Aerosols at a Molecular-Level - Identification, Abundance and SeasonalVariation, Atmos. Environ., Part a - General Topics, 27, 13091330, 1993 b.

Rogge, W. F., Hildemann, L. M., Mazurek, M. A., Cass, G. R., and Simoneit, B. R. T.: Sources of fine organic aerosol. 9. Pine, oak and synthetic log combustion in residential fireplaces, Environ. Sci. Technol., 32, 13-22, 1998.

Schauer, J. J., Rogge, W. F., Hildemann, L. M., Mazurek, M. A., 
and Cass, G. R.: Source apportionment of airborne particulate matter using organic compounds as tracers, Atmos. Environ., 30, 3837-3855, 1996.

Schauer, J. J. and Cass, G. R.: Source apportionment of wintertime gas-phase and particle-phase air pollutants using organic compounds as tracers, Environ. Sci. Technol., 34, 1821-1832, 2000.

Schauer, J. J., Fraser, M. P., Cass, G. R., and Simoneit, B. R. T.: Source reconciliation of atmospheric gas-phase and particlephase pollutants during a severe photochemical smog episode, Environ. Sci. Technol., 36, 3806-3814, 2002.

Simoneit, B. R. T.: Application of Molecular Marker Analysis to Vehicular Exhaust for Source Reconciliations, Int. J. Environ. An. Ch., 22, 203-233, 1985.

Simoneit, B. R. T., Rogge, W. F., Mazurek, M. A., Standley, L. J., Hildemann, L. M., and Cass, G. R.: Lignin Pyrolysis Products, Lignans, and Resin Acids as Specific Tracers of Plant Classes in Emissions from Biomass Combustion, Environ. Sci. Technol., 27, 2533-2541, 1993.

Simoneit, B. R. T., Schauer, J. J., Nolte, C. G., Oros, D. R., Elias, V. O., Fraser, M. P., Rogge, W. F., and Cass, G. R.: Levoglucosan, a tracer for cellulose in biomass burning and atmospheric particles, Atmos. Environ., 33, 173-182, 1999.

Simoneit, B. R. T.: Biomass burning - A review of organic tracers for smoke from incomplete combustion, Appl. Geochem., 17, 129-162, 2002.

Standley, L. J. and Simoneit, B. R. T.: Resin Diterpenoids as Tracers for Biomass Combustion Aerosols, J. Atmos. Chem., 18, 1-15, 1994.

Ward, T. J., Hamilton, R. F., Dixon, R. W., Paulsen, M., and Simpson, C. D.: Characterization and evaluation of smoke tracers in PM: Results from the 2003 Montana wildfire season, Atmos. Environ., 40, 7005-7017, 2006.
Yu, J. Z., Cocker, D. R., Griffin, R. J., Flagan, R. C., and Seinfeld, J. H.: Gas-phase ozone oxidation of monoterpenes: Gaseous and particulate products, J. Atmos. Chem., 34, 207-258, 1999a.

Yu, J. Z., Griffin, R. J., Cocker, D. R., Flagan, R. C., Seinfeld, J. H., and Blanchard, P.: Observation of gaseous and particulate products of monoterpene oxidation in forest atmospheres, Geophys. Res. Lett., 26, 1145-1148, 1999b.

Zhang, Q., Alfarra, M. R., Worsnop, D. R., Allan, J. D., Coe, H., Canagaratna, M. R., and Jimenez, J. L.: Deconvolution and quantification of hydrocarbon-like and oxygenated organic aerosols based on aerosol mass spectrometry, Environ. Sci. Technol., 39, 4938-4952, doi:10.1021/Es048568i, 2005.

Zheng, M., Cass, G. R., Schauer, J. J., and Edgerton, E. S.: Source apportionment of PM2.5 in the southeastern United States using solvent-extractable organic compounds as tracers, Environ. Sci. Technol., 36, 2361-2371, 2002.

Zheng, M., Ke, L., Edgerton, E. S., Schauer, J. J., Dong, M. Y., and Russell, A. G.: Spatial distribution of carbonaceous aerosol in the southeastern United States using molecular markers and carbon isotope data, J. Geophys. Res.-Atmos., 111, D10S06, doi:10.1029/2005JD006777, 2006.

Zheng, M., Cass, G. R., Ke, L., Wang, F., Schauer, J. J., Edgerton, E. S., and Russell, A. G.: Source apportionment of daily fine particulate matter at Jefferson street, Atlanta, GA, during summer and winter, J. Air Waste Manage. Assoc., 57, 228-242, 2007.

Zielinska, B., Sagebiel, J., McDonald, J. D., Whitney, K., and Lawson, D. R.: Emission rates and comparative chemical composition from selected in-use diesel and gasoline-fueled vehicles, J. Air Waste Manage. Assoc., 54, 1138-1150, 2004. 